\title{
Anthropometrical Characteristics and Somatotype of Young Macedonian Soccer Players
}

\author{
Características Antropométricas y Somatotipo de Jugadores Jóvenes de Fútbol Macedonios
}

\author{
Seryozha Gontarev"; Ruzdija Kalac"; Vujica Zivkovic"; Vullnet Ameti*** \& Agim Redjepi**
}

GONTAREV, S.; KALAC, R.; ZIVKOVIC, V.; AMETI, V. \& REDJEPI, R. Anthropometrical characteristics and somatotype of young Macedonian soccer players. Int. J. Morphol., 34(1):160-167, 2016.

SUMMARY: The success in sport performance is closely related to the physical condition of the sportsman. In the assessment of the physical status except physiological and fitness parameters, significant influence have the anthropometric parameters. The aim of the study was dual: to assess the changes in the anthropometric characteristics and the somatotype of young soccer players at different ages and to compare these characteristics with the general population. The analyzed measurements of 486 young soccer players who play in teams of the First national league, with an average age 15.8 \pm 1.4 . The soccer players were divided into five subgroups, at age difference of 1 year. In the sample height, weight, BMI index, diameters, volumes and skin folds were measured, also the body composition and the somatotype were calculated. Boys from 14 years were lower and had less tendencies of other age groups. From 16 years onwards there were no differences in the measurements which means that the respondents gradually get the look of adult players. All skin folds for young Macedonian players (except the skin folds of the scapula) decrease with age and compared to the peers from normal population are lower. For young players in all age groups dominate the mesomorphic component, and lower values have the endomorphic component, in regards to peers in the general population. The obtained results can serve as normative anthropometric indicators for regular sports medical examinations of young players in our country, or can be used as a template for comparison of the anthropometric and somatotype information of young players at a similar level of different countries.

\section{KEY WORDS: Soccer; Young; Anthropometry; Somatotype; Growth; Age.}

\section{INTRODUCTION}

Soccer has been the most popular sport in the world for over twenty years, regardless if it is observed from the aspect of the number of spectators or the number of active sportsman. During that period soccer has continuously developed, specifically aimed at increasing the physical demands and loads to which the soccer players are exposed to during the training and competitions. Modern soccer requires a much faster game, short response time, with less thinking and more demands with highly developed cognitive, functional and motor skills course (Markovic \& Bradic, 2008).

Anthropometry is widely applied in many scientific disciplines such as ergonomics and health science. Because of its convenience anthropometry is also used to understand the physical characteristics (performance) of the sportsman in the field of sports science which targets improvement of athletic performance (Mészáros et al., 2000). The assumption that anthropometric characteristics have influence on physical performance of the players have been proven in many studies (Bell \& Rhodes, 1975). The reported results provide evidence for sports officials (coaches, managers) as well as for football players about the importance of anthropometry (American Dietetic Association et al., 2009).

Players are expected to have specific morphological and physiological attributes and can therefore, have successful ongoing careers. A significant correlation between body mass, muscle mass and work-rate profile has been established (Rienzi et al., 2000). A research for young soccer players showed that age and physical characteristics are important indicators of talented player identification and selection for the game (Gil et al., 2007). Although the importance of anthropometric parameters are recognized in the selection process and training of the players, there is a lack of precise and accurate published information for

\footnotetext{
" Faculty of Physical Education, Sport, and Health, Ss. Cyril and Methodius University, Skopje, Macedonia.

** Faculty of Physical Education, State University of Tetovo, Tetovo, Macedonia.
} 
anthropometric characteristics of the players, especially for young players in the national league of our country. In addition there is a lack of comparative studies of anthropometric characteristics, body composition and somatotypes between Macedonian sportsmen and those of other countries.

The purpose of this paper is to determine the morphological characteristics, body composition, somatotype of the young players who play in clubs of the first league of the Republic of Macedonia and to determine the eventual differences in the researched parameters in terms of age and to compare these with the general population of same age, in order to create a successful training model for their football players and to identify young talented players.

The primary objective of this study is to determine the normative values of the anthropometric parameters and body composition and somatotype for young Macedonian male players. The results of this study can provide useful information for sports experts.

\section{MATERIAL AND METHOD}

Subjects. The research is realized in the Laboratory of Functional Testing, Department of Physiology and Anthropology at the Medical Faculty in Skopje, where all sportsman from the Republic of Macedonia are obligated to have regular medical-sports examination at least twice a year. Measurements were realized in 2013 when players have the mandatory medical-sports examinations.

The sample consisted of 486 young players who play in the best clubs of the first Macedonian league at the age of 14 to 18 years, with an average age of $15.8 \pm 1.4$. The sample was divided into five (5) different age groups: $14 \mathrm{y}(\mathrm{n}=111)$; 15 y $(n=111) ; 16$ y $(n=100) ; 17$ y $(n=88) ; 18$ y $(n=78)$. In the study we included all players whose parents gave consent to participate in the research. The Helsinki Declaration was applied.

The general population constitutes of 779 respondents at an age of 14 to $18 \mathrm{y}$, living in three urban regions in R. Macedonia. Of the schools included two were in the capital city, Skopje, and one school in each of the towns of Ohrid and Strumica. The respondents were measured for: body height, body weight, BMI index, two volumes (arm and leg), two diameters (elbow and knee) and four skin folds (triceps, subscapular, calf and abdominal). The information was taken from the doctoral dissertation Bojadzieva (Bojadzieva, 2015) and were sided with the young players.
Protocols and equipment. All measurements are conducted by high skilled, trained and experienced technicians. The height and weight were measured by using the stadometer (Seca, Leicester, UK) and electronic scale (HD-351, Tanita, Illinois, SAD). The skin folds were measured by the help of John Bull calipers. The circumferences were measured with a standard elastic measure tape, while the diameters by using sliding calipers (GPMc).

Besides height and weight the following anthropometric measures were measured: all four diameters (elbow, wrist, knee and ankle); five circumferences (upper arm, both relaxed and flexed, forearm, the calf and the thigh) as well as seven skin folds (biceps, triceps, forearm, thigh, calf, subscapular and abdominal). Anthropometric parameters were analyzed by a special software program that utilizes all Mateigka's formulas intended for calculations of all body components (Cattrysse et al., 2002). Somatotyping components (endomorphy - mesomorphy ectomorphy) were calculated according to Carter \& Heath (1990) method, using the somatotype software (SomatotypeV.1_2_5).

Statistical Methods. The data were analyzed using the Statistical Package for Social Sciences software (SPSS, v.22.0 for WINDOWS; SPSS Inc., Chicago, IL, USA), and values of $\mathrm{p}<0.05$ were considered statistically significant. Individual age groups were evaluated using a one-way analysis of the variance (ANOVA). Scheffé's test was used as a post-hoc test when equal variances were assumed and the Games-Howell test when equal variances could not be assumed.

\section{RESULTS}

Anthropometry. The players at $14 \mathrm{y}$ are lower and have lower body weight compared to all other age groups ( $\mathrm{p}$ $<0.001$ ). Their BMI index is also the lowest (Table I). The weight of the players at $15 \mathrm{y}$ is lower than the players at 17 and 18 y $(\mathrm{p}<0.05$ and their BMI index is statistically significantly lower than players at $18 \mathrm{y}(\mathrm{p}<0.01)$.

From the review of Table II it can be seen that the players at $14 \mathrm{y}$ have statistically significant smaller diameter of the elbow wrist compared to all other age groups. The circumferences of the upper arm and forearm are also statistically significantly lower compared to all other groups $(\mathrm{p}<0.05)$ and a smaller circumferences of the calf compared to the players of the 16,17 and 18 y age group ( $p<0.01$ ). Players at $15 \mathrm{y}$ have lower circumferences of the upper arm compared to players of 17 and 18 y age group $(p<0.01)$ and 
GONTAREV, S.; KALAC, R.; ZIVKOVIC, V.; AMETI, V. \& REDJEPI, R. Anthropometrical characteristics and somatotype of young Macedonian soccer players. Int. J. Morphol., 34(1):160-167, 2016.

Table I. Differences in weight $(\mathrm{kg})$, height $(\mathrm{cm})$ and BMI between soccer players by age group and comparison with the general population. The values are shown as the Mean \pm Standard Deviation.

\begin{tabular}{llccccc}
\hline & & \multicolumn{5}{c}{ Age group (years) } \\
\cline { 3 - 7 } & & $\mathbf{1 4}$ & $\mathbf{1 5}$ & $\mathbf{1 6}$ & $\mathbf{1 7}$ & $\mathbf{1 8}$ \\
\hline \multirow{2}{*}{ Soccer } & Height & $170.64 \pm 8.05 \mathrm{a}$ & $174.98 \pm 6.14 \mathrm{~b}$ & $176.38 \pm 6.77$ & $175.99 \pm 6.74$ & $177.08 \pm 6.46^{*}$ \\
players & Weight & $60.05 \pm 10.89 \mathrm{a}$ & $65.53 \pm 8.16 \mathrm{~b}$ & $68.70 \pm 7.51$ & $69.65 \pm 7.78$ & $70.08 \pm 7.46^{*}$ \\
& BMI & $20.13 \pm 3.69^{\mathrm{a}}$ & $21.37 \pm 2.12^{*}$ & $21.85 \pm 2.92$ & $22.18 \pm 2.92$ & $22.31 \pm 1.66^{*}$ \\
General & Height & $169.99 \pm 8.12$ & $173.68 \pm 7.13$ & $175.61 \pm 6.22$ & $177.77 \pm 7.07$ & $179.24 \pm 7.04^{*}$ \\
Population & Weight & $61.90 \pm 14.23$ & $67.28 \pm 12.76$ & $69.01 \pm 11.39$ & $70.92 \pm 12.48$ & $75.12 \pm 11.56^{*}$ \\
& BMI & $21.25 \pm 3.96^{*}$ & $22.25 \pm 3.75^{*}$ & $22.37 \pm 3.58$ & $22.41 \pm 3.58$ & $23.35 \pm 3.14^{*}$ \\
\hline
\end{tabular}

Differences between soccer players a - 14 years vs $15,16,17$ and 18 year-old groups, $p<0.00 ; b-15$ years vs 17 and 18 years, $p<0.05$; $\mathrm{c}-15$ years vs 18 years, $\mathrm{p}<0.01$; Comparison between the soccer players and the general population: ${ }^{*} \mathrm{p}<0.05$

Table II. Circumferences and diameters (Mean \pm Standard Deviation) in soccer players by age group and in the general population.

\begin{tabular}{|c|c|c|c|c|c|c|c|}
\hline & & & \multicolumn{5}{|c|}{ Age group (y ears) } \\
\hline & & & 14 & 15 & 16 & 17 & 18 \\
\hline \multirow{8}{*}{$\begin{array}{l}\text { Soccer } \\
\text { players }\end{array}$} & \multirow{4}{*}{$\begin{array}{l}\text { Diameters } \\
(\mathrm{cm})\end{array}$} & Wrist & $5.36 \pm 0.39$ & $5.38 \pm 0.32$ & $5.47 \pm 0.30$ & $5.46 \pm 0.33$ & $5.48 \pm 0.33$ \\
\hline & & Knee & $9.98 \pm 0.64 *$ & $10.04 \pm 0.47 *$ & $10.11 \pm 0.42 *$ & $10.01 \pm 0.48 *$ & $9.92 \pm 0.64 *$ \\
\hline & & Elbow & $7.42 \pm 0.69 \mathrm{a}^{*} *$ & $7.64 \pm 0.46^{*}$ & $7.79 \pm 0.47 *$ & $7.77 \pm 0.59 *$ & $7.86 \pm 0.50 *$ \\
\hline & & Ankle & $7.12 \pm 0.48$ & $6.97 \pm 0.50$ & $7.11 \pm 0.48$ & $7.09 \pm 0.55$ & $7.19 \pm 0.52$ \\
\hline & \multirow{4}{*}{$\begin{array}{l}\text { Circumference } \\
(\mathrm{cm})\end{array}$} & Upper arm & $24.78 \pm 2.64^{\mathrm{a}^{*}}$ & $25.74 \pm 2.36 \mathrm{c} *$ & $26.62 \pm 1.82 *$ & $27.21 \pm 2.15^{*}$ & $27.26 \pm 2.17^{*}$ \\
\hline & & Thigh & $51.14 \pm 5.21$ & $53.59 \pm 3.88 \mathrm{~d}$ & $54.99 \pm 3.34$ & $55.00 \pm 3.47$ & $55.50 \pm 3.37$ \\
\hline & & For earm & $23.55 \pm 2.23^{\mathrm{a}}$ & $24.43 \pm 1.67^{\mathrm{c}}$ & $25.06 \pm 1.42$ & $25.35 \pm 1.62$ & $25.53 \pm 1.51$ \\
\hline & & Calf & $34.63 \pm_{2.99 b}$ & $35.45 \pm 2.37$ & $36.27 \pm 2.29$ & $36.11 \pm 2.37$ & $36.33 \pm 2.34$ \\
\hline General & Diameters & Knee & $9.38 \pm 0.82 *$ & $9.30 \pm 0.72 *$ & $9.60 \pm 0.63 *$ & $9.63 \pm 0.74 *$ & $9.57 \pm 0.65^{*}$ \\
\hline \multirow[t]{3}{*}{ Population } & $(\mathrm{cm})$ & Elbow & $6.54 \pm 0.51 *$ & $6.54 \pm 0.45^{*}$ & $6.58 \pm 0.44 *$ & $6.68 \pm 0.41^{*}$ & $6.87 \pm 0.44^{*}$ \\
\hline & Circumference & Upper arm & $27.18 \pm 3.69 *$ & $28.41 \pm 3.70 *$ & $28.61 \pm 3.69 *$ & $29.55 \pm 3.55^{*}$ & $31.49 \pm 3.40^{*}$ \\
\hline & $(\mathrm{cm})$ & Calf & $34.80 \pm 4.43$ & $34.64 \pm 3.67$ & $35.38 \pm 3.25$ & $35.47 \pm 3.83$ & $37.11 \pm 3.11$ \\
\hline
\end{tabular}

Differences between soccer players a - 14 years vs $15,16,17$ and 18 year-old groups, circumference, $p<0.05$ diameters $p<0.05$; $b-15$ years vs 16,17 and 18 years, $\mathrm{p}<0.05 ; \mathrm{c}-15$ years vs 17 and 18 year-old groups $\mathrm{p}<0.01 ; \mathrm{d}-15$ years vs 18 years. Comparison between the soccer players and the general population: *p<0.05.

lower circumferences of thigh in relation to players of $18 \mathrm{y}$ age group $(\mathrm{p}<0.05)$.

From the review of the Table III it can be seen that players at $14 \mathrm{y}$ have statistically significant greater value of forearm skin folds compared to all other age groups ( $p$ $<0.01$ ), greater value of thigh skin folds compared to the players of 17 and $18 \mathrm{y}(\mathrm{p}<0.05)$ and calf regarding to the players of 16,17 and $18 \mathrm{y}(\mathrm{p}<0.001)$ Also, players at $14 \mathrm{y}$ have significantly higher value of upper arm skin folds (triceps and biceps) compared to players of $18 \mathrm{y}$ age group ( $p<0.05)$. Players at 15 y have statistically significant higher value of shin skin folds compared to players of 17 and $18 \mathrm{y}$ $(\mathrm{p}<0.01)$ and on the forearm in terms of the players of $18 \mathrm{y}$ age group $(\mathrm{p}<0.01)$.

Body composition. From the values of the arithmetic means and the level of statistical significance in Table IV, it can be seen that the players at $14 \mathrm{y}$ have a statistically significant lower absolute values of muscle and fat mass compared to all other age groups $(\mathrm{p}<0.01)$ and smaller absolute values of bone mass in terms of players at 16 and 18 y $(p<0.01)$. Players at $15 \mathrm{y}$ have lower absolute values of muscle mass compared to players at 17 and 18 y $(\mathrm{p}<0.05)$.

As for the percentage differences of the components of the body (Table IV), it can be seen that the players at $14 \mathrm{y}$ have a statistically significant largest percentage values of bone mass compared to all other age groups $(p<0.001)$ and smaller percentage values of muscle mass in terms of 16 and $18 \mathrm{y}(\mathrm{p}<0.05)$. The players at $15 \mathrm{y}$ have higher percent of bone mass compared to players of $17 \mathrm{y}(\mathrm{p}<0.05)$. Statistically significant differences were not determined in the percentage values of fat component among different age groups.

Somatotype. In Table V the average values of ectomorphic, mesomorphic and endomorphic components are shown. In all age groups mesomorphy component of the somatotype dominates. For the youngest players the average values of ectomorphy component are statistically significantly higher compared to other players from all age groups $(\mathrm{p}<0.05)$. 
Table III. Individual skinfolds ( $\mathrm{mm}$ ) (Mean \pm Standard Deviation) of six sites in soccer players by age group and their comparison with the general population.

\begin{tabular}{llccccc}
\hline & & \multicolumn{3}{c}{ Age group (y ears) } \\
\cline { 3 - 6 } & & $\mathbf{1 4}$ & $\mathbf{1 5}$ & $\mathbf{1 6}$ & $\mathbf{1 7}$ & $\mathbf{1 8}$ \\
\hline S occer players & Bice ps & $6.52 \pm 6.23^{\mathrm{d}}$ & $6.04 \pm 5.35$ & $4.96 \pm 1.14$ & $4.90 \pm 1.31$ & $4.66 \pm 1.06$ \\
& Fore $\mathrm{arm}$ & $7.29 \pm 1.75^{\mathrm{a}}$ & $6.62 \pm 1.37^{\mathrm{f}}$ & $6.20 \pm 1.30$ & $6.06 \pm 1.37$ & $5.79 \pm 1.15$ \\
& Triceps & $9.80 \pm 3.35^{\mathrm{d} *}$ & $9.32 \pm 2.81^{*}$ & $8.91 \pm 2.73^{*}$ & $8.54 \pm 2.80^{*}$ & $8.09 \pm 2.45^{*}$ \\
& Thigh & $14.94 \pm 5.17^{\mathrm{b}}$ & $14.26 \pm 4.53^{\mathrm{e}}$ & $13.03 \pm 3.90$ & $12.75 \pm 3.97$ & $12.70 \pm 4.69$ \\
& Subscapular & $8.77 \pm 3.19^{*}$ & $8.79 \pm 2.48^{*}$ & $9.53 \pm 2.66^{*}$ & $9.67 \pm 2.58^{*}$ & $9.31 \pm 2.87^{*}$ \\
& Calf & $12.23 \pm 3.56^{\mathrm{c}}$ & $11.36 \pm 3.11$ & $10.24 \pm 3.10$ & $9.75 \pm 3.04^{*}$ & $8.82 \pm 2.68^{*}$ \\
& Abdominal & $9.00 \pm 4.00^{*}$ & $8.58 \pm 2.96^{*}$ & $8.33 \pm 3.09^{*}$ & $8.08 \pm 2.4^{*}$ & $8.20 \pm 3.00^{*}$ \\
General & Triceps & $12.45 \pm 6.26^{*}$ & $12.72 \pm 7.15^{*}$ & $12.04 \pm 5.69^{*}$ & $12.17 \pm 7.08^{*}$ & $12.09 \pm 4.84^{*}$ \\
Population & Subscapular & $9.98 \pm 5.55^{*}$ & $10.63 \pm 5.62^{*}$ & $10.57 \pm 4.27^{*}$ & $11.23 \pm 4.93^{*}$ & $11.84 \pm 4.22^{*}$ \\
& Calf & $11.59 \pm 5.55$ & $12.50 \pm 6.22$ & $11.26 \pm 5.10$ & $11.30 \pm 5.38^{*}$ & $10.70 \pm 4.61^{*}$ \\
& Abdominal & $11.72 \pm 7.87^{*}$ & $11.77 \pm 7.61^{*}$ & $10.90 \pm 6.05^{*}$ & $11.70 \pm 7.06^{*}$ & $12.65 \pm 6.36^{*}$ \\
\hline
\end{tabular}

Differences between soccer players a - 14 years vs $15,16,17$ and 18 year-old groups $p<0.01$; b - 14 years vs 17 and 18 year-old groups $p<0.05$; -14 years vs 16,17 and 18 year-old groups $p<0.00 ; d-14$ years vs 18 year-old groups $p<0.05$; e -15 years vs 17 and 18 year-old groups $p<0.01$; $f-15$ years vs 18 year-old groups $\mathrm{p}<0.01$. Comparison between the soccer players and the general population: $* \mathrm{p}<0.05$.

Table IV. Body composition of soccer players by age. The means and standard deviations of fat, bone and muscle weights $(\mathrm{kg})$ and percentages are shown.

\begin{tabular}{lccccc}
\hline & \multicolumn{5}{c}{ Age group (years) } \\
\cline { 2 - 6 } & $\mathbf{1 4}$ & $\mathbf{1 5}$ & $\mathbf{1 6}$ & $\mathbf{1 7}$ & $\mathbf{1 8}$ \\
\hline MMkg & $31.05 \pm 6.73^{\mathrm{a}}$ & $34.07 \mathrm{c} \pm 5.26$ & $36.37 \pm 4.48$ & $36.75 \pm 5.28$ & $37.49 \pm 4.89$ \\
BMkg & $11.55 \pm 1.89^{\mathrm{b}}$ & $11.91 \pm 1.37$ & $12.45 \pm 1.31$ & $12.23 \pm 1.58$ & $12.37 \pm 1.44$ \\
FMkg & $8.99 \pm 2.33$ & $9.75 \pm 2.19$ & $10.14 \pm 1.74$ & $10.22 \pm 1.69$ & $10.12 \pm 1.82$ \\
MM\% & $51.39 \pm 4.10^{\mathrm{b}}$ & $51.91 \pm 3.94$ & $52.96 \pm 3.25$ & $52.67 \pm 3.49$ & $53.42 \pm 2.91$ \\
BM\% & $19.32 \pm 1.77^{\mathrm{a}}$ & $18.29 \mathrm{~d} \pm 1.81$ & $18.19 \pm 1.45$ & $17.58 \pm 1.41$ & $17.67 \pm 1.31$ \\
FM\% & $14.79 \pm 1.75$ & $14.79 \pm 2.34$ & $14.71 \pm 1.47$ & $14.64 \pm 1.46$ & $14.38 \pm 1.42$ \\
LBM & $51.21 \pm 8.81$ & $55.78 \pm 6.64$ & $58.55 \pm 6.19$ & $59.43 \pm 6.50$ & $59.96 \pm 6.01$ \\
\hline
\end{tabular}

Differences between soccer players a - 14 years vs $15,16,17$ and 18 year-old groups $p<0.01 ; b-14$ years vs, 16 , and 18 year-old groups $\mathrm{p}<0.05 ; \mathrm{c}-15$ years vs, 17 , and 18 year-old groups $\mathrm{p}<0.05 ; \mathrm{d}-15$ years vs, 17 year-old groups $\mathrm{p}<0.05$.

The players at 15 y have statistically significant higher values of ectomorphy component in terms of the player at 17 y $(\mathrm{p}<0.05)$.

Comparison to the general population. The information that we used for comparison is measured on boys at the age of 14 to $18 \mathrm{y}$. Based on the obtained results (Tables I to V) it can be seen that the players of all age groups have greater knee and elbow diameter, show lower values of skin fold of triceps, scapula and abdomen and have lower circumferences of upper arm relative to their peers in the general population. Also, players from 14, 15 and $18 \mathrm{y}$ have lower values of BMI index relative to peers. Players at 17 and $18 \mathrm{y}$ have smaller values of skin folds of thighs, while players at $18 \mathrm{y}$ have smaller body weight and height compared to peers in the general population.

Table V. Scores (Mean \pm Standard Deviation) of the three components of the somatotype of soccer players by age and the scores for the general population.

\begin{tabular}{llccccc}
\hline & & \multicolumn{3}{c}{ Age group (y ears) } \\
\cline { 3 - 6 } & & $\mathbf{1 4}$ & $\mathbf{1 5}$ & $\mathbf{1 6}$ & $\mathbf{1 7}$ & $\mathbf{1 8}$ \\
\hline Soccer players & Endomorphic & $2.74 \pm 0.94^{*}$ & $2.63 \pm 0.88^{*}$ & $2.58 \pm 0.75^{*}$ & $2.54 \pm 0.72^{*}$ & $2.44 \pm 0.72^{*}$ \\
& Mesomorphic & $4.37 \pm 1.18^{*}$ & $4.38 \pm 1.10^{*}$ & $4.76 \pm 1.13^{*}$ & $4.76 \pm 1.10^{*}$ & $4.68 \pm 1.08^{*}$ \\
& Ectomorphic & $3.48^{-1.15} \mathrm{a}$ & $3.28^{ \pm} 1.05 \mathrm{~b}$ & $3.01 \pm 0.99$ & $2.78 \pm 0.81$ & $2.91 \pm 0.85$ \\
General Population & Endomorphic & $3.35 \pm 1.76^{*}$ & $3.40 \pm 1.78^{*}$ & $3.24 \pm 1.43^{*}$ & $3.37 \pm 1.67^{*}$ & $3.47 \pm 1.3^{*}$ \\
& Mesomorphic & $3.77 \pm 1.61^{*}$ & $3.51 \pm 1.58^{*}$ & $3.58 \pm 1.56^{*}$ & $3.73 \pm 1.47^{*}$ & $4.13 \pm 1.41^{*}$ \\
& Ectomorphic & $3.22 \pm 1.64$ & $2.93 \pm 1.47$ & $3.01 \pm 1.49$ & $3.02 \pm 1.53$ & $2.69 \pm 1.33$ \\
\hline
\end{tabular}

Differences between soccer players at - 14 years vs $15,16,17$ and 18 year-old groups $p<0.05$; $b-15$ years vs, 17 year-old groups $p<0.05$; Comparison between the soccer players and the general population: $* \mathrm{p}<0.05$. 
As for the somatotype, endomorphy component shows lower values, mesomorphy higher compared to peers in the general population (Table V), all differences were statistically significant. From the Table it can be seen that young players tend to have higher mesomorphy and ectomorphy scores, while boys in the general population have higher endomorphy.

\section{DISCUSSION}

There are a number of studies that research the anthropometric characteristics and somatotype for best players, or comparative research among elite and non-elite players. The advantage of this study is that anthropometric measurements are conducted on a relative large sample of young elite players from the Republic of Macedonia from the best clubs in the first league. The results of this research can serve as normative values for comparison of anthropometric and somatotype information for young players in our country.

The research results suggest that players at $14 \mathrm{y}$, compared to all other age groups (15 to 18) have less body weight and height, BMI index, smaller elbow diameter, circumferences of the upper arm and forearm. Also, players at $14 \mathrm{y}$ have lower circumference of calf compared to players of 16,17 and $18 \mathrm{y}$.

Players of 15 y show smaller values of some anthropometric measures in relation to players of 16,17 and $18 \mathrm{y}$. On this basis it can be concluded that boys at 14 and 15 years have not completed their growth process. From $16 \mathrm{y}$ onwards, the progression of the height is decreasing that point so these soccer players gradually achieve the height, weight, diameters and circumferences of adult players. The average height of adult Macedonian soccer players (over $20 \mathrm{y}$ ) is $178 \mathrm{~cm}$, while the weight ranges from 72 to $77 \mathrm{~kg}$ (PluncevicGligoroska et al., 2014).

Comparing the players with their peers from the general population, it may be noted that up to 17 years no differences in height and weight were observed, while players from 18 years have lower body height and weight compared to their peers in the general population. If we compare the results of our research with young players from other countries we may conclude that the height and weight is similar to young players from Croatia (Jankovic et al., 1993), Bulgaria (Toteva, 2002; Hulse, 2010), Portugal (Capela et al., 2005), Brazil (Goncalves et al., 2007). Slightly higher are players from Swiss (Tschopp et al., 2005), Norway (Helgerud et al., 2001) and Spain (Tschopp et al.; Hulse).
One of the largest studies of morphological and physical characteristics of young elite players is realized by Hulse. The research was realized on sample of 2252 respondents from U9 to U19. Comparing the results of our research with the results obtained in this study can be seen that the Macedonian players from 14 to $16 \mathrm{y}$ are taller and heavier that the young English players who are members of English professional soccer academies. On the other hand, the English players from 17 to $18 \mathrm{y}$ are higher and heavier than the Macedonian players.

Observations of the height and weight of players from different geographical regions show that the players vary significantly in that sense. Such differences may be as a results of ethnic and cultural influences or result of a different style of soccer, where teams from different leagues prefer different kinds of players for certain positions (Bloomfield et al., 2005). However, when making a general comparison between the players of sports games and the general population, results show that soccer players on average are similar in height with the general population (Norton \& Olds, 2001; Matkovic et al., 2003). In a number of researches it is found that physical activity does not affect body measurements, growth-velocity, bone maturation (Beunen et al., 1992; Damsgaard et al., 2001; Malina, 1994) or adult height (Malina).

All skin folds for young Macedonian players (except the skin folds of the scapula) decreases with the age and are lower compared to peers from normal population. The highest reduction in skin folds from year to year is seen in the lower limb, which is probably a result of the training process and competitions. Cacciari et al. (1990) have come to results that players in puberty of 12 and $14 \mathrm{y}$ had smaller skin folds (triceps and sub-scapula) than inactive controlled group. These differences support the suggestions that physical training can lead to increased muscle and reduce body fat (Cacciari et al.). On the basis of everything stated above it can be concluded that the pattern of growth of the Macedonian young players is similar to the growth of children from the general population and also suitable for their age (Rogol et al., 2002).

The amount of fat component in the body is important from a physiological point of view, greater percentage of body fat is a natural correlation with the physical predisposition of the sportsman, especially those movements that move the body or individual body parts in space (Gil et al.). The percentage of fat component of the Macedonian young players is around $14 \%$ and is similar to the percentage of fat component of Macedonian adult soccer players (over 20 y) (Pluncevic-Gligoroska et al.). The average values of the body fat percentage in our study 
population were found at the higher zone of the optimal level (5-15\%) delineated by Heyward \& Wagner (2004) for a physically active male population. Body fat in Portuguese junior football players calculated by Matiegka's method was $11.7 \%$ (Salgado et al., 2010). Macedonian young players have higher values of the fat component compared to other studies (Tabara et al., 2006; Le Gall et al., 2010; Reilly et al., 2010). However, these values should be taken with a certain degree of reserve, because one of the problems in the body comparison of the body composition is applied with different formulas or methods for assessment.

As for the somatotype, the main component in this sample of young players is mesomorphic. It is logical that the muscle composition is beneficial to carry out the various activities during the competition because these activities define the outcome of the competition, for example, start on the opponent, acceleration, kicking and building the ball. Given the nature of the game, the expressed muscle development is evident on the lower part of the body, rather than the upper. The age group of 14 years showed the highest values of ectomorphy component in relation to all other age groups. This is because at this age the players are underweight in relation to height. Similar results were obtained in the general population (Rosique, 1992) and for young players.

When we compare the somatotype of the players with the general population, the most striking differences were determined in endomorphic component, which is correlated with the total amount of fat components. Players of all age groups had lower values of endomorphic component, relative to peers in the general population. This is a very important issue nowadays which is due to the cause-and-effect relationship between the lack of physical activity and chronic diseases such as obesity and metabolic syndrome, which is observed in many research studies (van Lenthe et al., 1996).

\section{CONCLUSIONS}

The anthropometric characteristics of the players can be an indicator of physical readiness of the sportsman and therefore the anthropometric examination is an important segment of the physical (sport) examination of the sportsman. The youngest group of the soccer players (age 14 y) showed significant differences in several parameters in relation of all other age groups. Soccer players have a large elbow and knee diameter, show smaller values of the fat and endomorphic component, and greater muscle and mesomorphic component in relation to the peers in the general population. The obtained results can serve as normative anthropometric indicators for regular sports medical examinations of young players in our country. The information can also be used as a template for comparison of anthropometric and somatotype information of young players at a similar level from different countries.

GONTAREV, S.; KALAC, R.; ZIVKOVIC, V.; AMETI, V. \& REDJEPI, R. Características antropométricas y somatotipo de jugadores jóvenes de futbol macedonios. Int. J. Morphol., 34(1):160-167, 2016.

RESUMEN: El éxito en el rendimiento deportivo está estrechamente relacionado con el estado físico del deportista. En la evaluación de la condición física, excepto los parámetros fisiológicos y de acondicionamiento físico, los parámetros antropométricos tienen una influencia significativa. El objetivo del estudio fue evaluar los cambios en las características antropométricas y de somatotipo de jugadores jóvenes de fútbol de diferentes edades y comparar estas características con la población general. Las mediciones analizadas fueron de 486 futbolistas jóvenes que juegan en equipos de la Primera Liga Nacional, con una edad media de 15,8 $\pm 1,4$. Los futbolistas fueron divididos en cinco subgrupos, con diferencias de edad de un año. En la muestra se midieron altura, peso, índice de masa corporal (IMC), diámetros, volúmenes y pliegues de la piel. También se calcularon la composición corporal y somatotipo. Estos fueron menores en niños de 14 años y tuvieron menores tendencias que otros grupos etarios. De 16 años en adelante, no hubo diferencias en las mediciones, lo que indica que los encuestados obtienen gradualmente el aspecto de jugadores adultos. Todos los pliegues de la piel en los jugadores jóvenes macedonios (excepto los pliegues de la piel de la escápula) disminuyen con la edad y en comparación con los compañeros pertenecientes a la población normal, son más bajos. Para los jugadores jóvenes de todas las edades domina el componente mesomórfico, y los valores más bajos tienen el componente endomorfo, en lo que respecta a sus compañeros de la población general. Los resultados obtenidos pueden servir de indicadores antropométricos para establecer normativas para los exámenes médicos en jugadores jóvenes de Macedonia, pudiendo también ser utilizados como una plantilla para la comparación del somatotipo antropométrico de los jugadores jóvenes en niveles similares de diferentes países.

PALABRAS CLAVE: Fútbol; Joven; Antropometría; Somatotipo; Crecimiento; Edad. 


\section{REFERENCES}

American Dietetic Association; Dietitians of Canada; American College of Sports Medicine; Rodriguez, N. R.; Di Marco, N. M. \& Langley, S. American College of Sports Medicine position stand. Nutrition and athletic performance. Med. Sci. Sports Exerc., 41(3):709-31, 2009.

Bell, W. \& Rhodes, G. The morphological characteristics of the association football player. Br. J. Sports Med., 9(4):196-200, 1975.

Beunen, G. P.; Malina, R. M.; Renson, R.; Simons, J.; Ostyn, M. \& Lefevre, J. Physical activity and growth, maturation and performance: a longitudinal study. Med. Sci. Sports Exerc., 24(5):576-85, 1992.

Bloomfield, J.; Polman, R. Butterly, R. \& O'Donoghue, P. Analysis of age, stature, body mass, BMI and quality of elite soccer players from 4 European Leagues. J. Sports Med. Phys. Fitness, 45(1):58-67, 2005.

Bojadzieva, S. B. Somatotype and morphological characteristics of adolescents aged 11 to 18 years in the Republic of Macedonia. Unpublished Doctoral Dissertation. Skopje, The Saints Cyril \& Methodius University of Skopje, 2015.

Cacciari, E.; Mazzanti, L.; Tassinari, D.; Bergamaschi, R.; Magnani, C.; Zappulla, F.; Nanni, G.; Cobianchi, C.; Ghini, T.; Pini, R. \& Tani, G. Effects of sport (football) on growth: auxological, anthropometric and hormonal aspects. Eur. $J$. Appl. Physiol. Occup. Physiol., 61(1-2):149-58, 1990.

Capela, C.; Fragosol, I.; Vieira, F.; Mil-Homens, P. \& GomesPereira, J. Physical Performance Tests in Young Soccer Players with Reference to Maturation. In: Reilly, T.; Cabri, J. \& Araújo, D. (Eds.). Science and Football V. The Proceedings of the Fifth World Congress on Science and Football. London, Routledge, 2005. pp.196-7.

Carter, J. E. L. \& Heath, B. H. Somatotyping. Development and Applications. Cambridge (NY), Cambridge University Press, 1990.

Cattrysse, E.; Zinzen, E.; Caboor, D.; Duquet, W.; Van Roy, P. \& Clarys, J. P. Anthropometric fractionation of body mass: Matiegka revisited. J. Sports Sci., 20(9):717-23, 2002.

Damsgaard, R.; Bencke, J.; Matthiesen, G.; Petersen, J. H. \& Müller, J. Body proportions, body composition and pubertal development of children in competitive sports. Scand. J. Med. Sci. Sports, 11(1):54-60, 2001.

Gil, S. M.; Gil J.; Ruiz, F.; Irazusta, A. \& Irazusta, J. Physiological and anthropometric characteristics of young soccer players according to their playing position: relevance for the selection process. J. Strength Cond. Res., 21(2):438-45, 2007.
Goncalves, L.; Garcia, C., \& Hespanhol, J. Fitness profile of under-15 Brazilian soccer players by field position. J. Sports Sci. Med., 10:110-8, 2007.

Helgerud, J.; Engen, L. C.; Wisloff, U. \& Hoff, J. Aerobic endurance training improves soccer performance. Med. Sci. Sports Exerc., 33(11):1925-31, 2001.

Heyward, V. H. \& Wagner, D. R. Applied Body Composition Assessment. Champaigne (IL), Human Kinetics, 2004.

Hulse, M. A. Physical development, and progression to professional soccer, of elite child and adolescent academy players. PhD Thesis. Loughborough, Loughborough University, School of Sport Exercise and Health Sciences, 2010 .

Jankovic, S.; Heimer, N. \& Matkovic, B. R. Physiological Profile of Prospective Soccer Players. In: Reilly, T.; Clarys, J. P. \& Stibbe, A. (Eds.). Science and Football II: Proceedings of the Second World Congress of Science and Football, Eindhoven, Netherlands, 22nd-25th May, 1991. London, E \& FN Spon, 1993. pp.295-7.

Le Gall, F.; Carling, C.; Williams, M. \& Reilly, T. Anthropometric and fitness characteristics of international, professional and amateur male graduate soccer players from an elite youth academy. J. Sci. Med. Sport, 13(1):90-5, 2010.

Malina, R. M. Physical activity and training: effects on stature and the adolescent growth spurt. Med. Sci. Sports Exerc., 26(6):759-66, 1994.

Markovic, G. \& Bradic, A. Nogomet: Integralni kondicijski trening. Zagreb, GEA Sport, 2008.

Matkovic, B. R.; Misigoj-Durakovic, M.; Matkovic, B.; Jankovic, S.; Ruzic, L.; Leko, G. \& Kondric, M. Morphological differences of elite Croatian soccer players according to the team position. Coll. Antropol., 27(Suppl. 1):167-74, 2003.

Mészáros, T.; Mohácsi, J.; Szabó, T. \& Szmodis, I. Anthropometry and competitive sport in Hungary. Acta Biol. Szeged., 44:18992, 2000 .

Norton, K. \& Olds, T. Morphological evolution of athletes over the 20th century: causes and consequences. Sports Med., 31(11):763-83, 2001.

Pluncevic-Gligoroska, J.; Todorovska, L.; Dejanova, B.; Maleska, V.; Mancevska, S. \& Nikolic, S. Anthropometric parameters in national footballers in the Republic of Macedonia. Prilozi, 35(2):147-54, 2014. 
Reilly, J. J.; Kelly, J. \& Wilson, D. C. Accuracy of simple clinical and epidemiological definitions of childhood obesity: systematic review and evidence appraisal. Obes. Rev., 11(9):645-55, 2010.

Rienzi, E.; Drust, B.; Reilly, T.; Carter, J. E. \& Martin, A. Investigation of anthropometric and work-rate profiles of elite South American international soccer players. J. Sports Med. Phys. Fitness, 40(2):162-9, 2000.

Rogol, A. D.; Roemmich, J. N. \& Clark, P. A. Growth at puberty. J. Adolesc. Health, 31(6 Suppl.):192-200, 2002.

Rosique, G. J. Estudio transversal del crecimiento en escolares Vizcaínos. Lavariación antropométrica como componente de la estructura biológica de la población. $\mathrm{PhD}$ Thesis. Leioa, Universitat de Valencia, 1992.

Salgado, B.; Vidal, S.; Silva, S.; Miranda, R.; Deus, R.; Garganta, R.; Maia, J.; Rebelo, A. \& Seabra, A. Somatotype and body composition. In: Portuguese youth soccer players. Drust, B.; Reilly, T. \& Williams, A. M. (Eds.). International Research. In: Science and Soccer: The proceedings of the first world conference on science and soccer. London, Routledge, 2010.

Tabara, Y.; Moji, K.; Tsunawake, N.; Fukuda, R.; Nakayama, M.; Nakagaichi, M.; Komine, T.; Kusano, Y. \& Aoyagi, K. Physique, body composition and maximum oxygen consumption of selected soccer players of Kunimi High School, Nagasaki, Japan. J. Physiol. Anthropol., 25(4):2917, 2006.

Toteva, M. Somatotype characteristics of young football players. In: Spinks, W.; Reilly, T. \& Murphy, A. Science and Football IV. Proceedings of the 4th World Congress of Science and Football. Nueva York, Routledge, 2002. pp.263-4.

Tschopp, M.; Held, T. \& Marti, B. Four year development of physiological factors of junior elite soccer players aged between 15-16 years. In: Reilly, T.; Cabri, J. \& Araújo, D. (Eds.). Science and Football V: The Proceedings of the Fifth World Congress on Sports Science and Football. London, Routledge, 2005. pp.307-8.

van Lenthe, F. J.; Kemper, H. C.; van Mechelen, W.; Post, G. B.; Twisk, J. W.; Welten, D. C. \& Snell, J. Biological maturation and the distribution of subcutaneous fat from adolescence into adulthood: the Amsterdam Growth and Health Study. Int. J. Obes. Relat. Metab. Disord., 20(2):121-9, 1996.

\author{
Correspondence to: \\ Seryozha Gontarev \\ Faculty of Physical Education, Sport and Health \\ Dimce Mircev no.3 \\ 1000 Skopje \\ REPUBLIC OF MACEDONIA
}

Email: gontarevserjoza@gmail.com

Received: 10-09-2015

Accepted: 23-12-2015 